\title{
Pengaruh Self-Efficacy Terhadap Kemandirian Belajar Siswa
}

\author{
Tania Nur Hanifah ${ }^{1}$, Ajang Mulyadi ${ }^{2}$, Heraeni Tanuatmodjo ${ }^{3}$ \\ Program Studi Pendidikan Akuntansi, FPEB, Universitas Pendidikan Indonesia, Bandung, Indonesia ${ }^{1}$ \\ Program Studi Pendidikan Akuntansi, FPEB, Universitas Pendidikan Indonesia, Bandung, Indonesia ${ }^{2}$ \\ Program Studi Pendidikan Akuntansi, FPEB, Universitas Pendidikan Indonesia, Bandung, Indonesia ${ }^{3}$
}

\begin{abstract}
This study aims to describe the student's self-efficacy, student learning independence, as well as the effect of self-efficacy on the learning independence of class XI Accounting 2016/2017 academic year in Financial Accounting subjects at SMK Negeri 1 Bandung. This study uses descriptive and verification methods. Data collection techniques in the form of questionnaires distributed to the entire population of students of class XI Accounting 2016/2017 academic year at SMK Negeri 1 Bandung, amounting to 105 people. Questionnaire self-efficacy is composed of 28 item statements with 11 alternative answers and learning independence questionnaire composed of 19 statement items with 5 alternative answers. The normality test uses the Kolmogorov-Smirnov test formula and correlation analysis using the Pearson product moment formula. All data processing uses Microsoft Statistical Product and Service Solution (SPSS) software version 23.0. From the calculation of the t test, it is known that tcounttable, so it can be concluded that self-efficacy has a positive effect on the learning independence of class XI Accounting students in the 2016/2017 academic year in Financial Accounting subjects at SMK Negeri 1 Bandung.

Keywords. self-efficacy; learning independence
\end{abstract}

\begin{abstract}
Abstrak
Penelitian ini bertujuan untuk mengetahui gambaran self-efficacy siswa, kemandirian belajar siswa, serta pengaruh self-efficacy terhadap kemandirian belajar siswa kelas XI Akuntansi tahun ajaran 2016/2017 dalam mata pelajaran Akuntansi Keuangan di SMK Negeri 1 Bandung. Penelitian ini menggunakan metode deskriptif dan verifikatif. Teknik pengumpulan data berupa angket yang disebarkan kepada seluruh populasi siswa kelas XI Akuntansi tahun ajaran 2016/2017 di SMK Negeri 1 Bandung yang berjumlah 105 orang. Angket selfefficacy tersusun dari 28 item pernyataan dengan 11 alternatif jawaban dan angket kemandirian belajar tersusun dari 19 item pernyataan dengan 5 alternatif jawaban. Uji normalitas menggunakan rumus uji KolmogorovSmirnov dan analisis korelasi menggunakan rumus Pearson product moment. Seluruh pengolahan data menggunakan software Microsoft Statistical Product and Service Solution (SPSS) versi 23.0. Dari perhitungan uji $\mathrm{t}$ diketahui $\mathrm{t}_{\text {hitung }}>\mathrm{t}_{\text {tabel }}$, sehingga ditarik kesimpulan bahwa self-efficacy berpengaruh postitif terhadap kemandirian belajar siswa kelas XI Akuntansi tahun ajaran 2016/2017 dalam mata pelajaran Akuntansi Keuangan di SMK Negeri 1 Bandung.
\end{abstract}

Kata Kunci: self-efficacy; kemandirian belajar

Corresponding author. Email.tania@gmail.com ${ }^{1}$, ajangmulyadi@upi.edu ${ }^{2}$, heraenitanuatmodjo@upi.edu ${ }^{3}$

How to cite this article. Tania, N. H., Mulyadi, A., \& Tanuatmodjo, H. (2017). Pengaruh Self-Efficacy Terhadap Kemandirian Belajar Siswa. Jurnal Pendidikan Akuntansi Dan Keuangan, 5(2), 107-116. Retrieved from http://ejournal.upi.edu/index.php/JPAK/article/view/15411

History of article. Received: Februari 2017, Revision: Mei 2017, Published: Juli 2017

\section{Pendahuluan}

Mata pelajaran Akuntansi Keuangan sebagian besar melibatkan kemampuan siswa dalam berhitung. Hal ini cenderung akan menimbulkan efek jenuh terhadap siswa dan tentu dapat mempengaruhi konsentrasi siswa saat menerima pelajaran. Jika hanya terpaku pada guru sebagai pendidik dan proses pembelajaran yang terjadi di kelas, proses belajar siswa akan terhambat. Untuk itu diperlukan kegiatan belajar intensif dan kesadaran dari dalam diri siswa akan pentingnya menerapkan kemandirian belajar untuk meningkatkan hasil belajar. Sumarmo (2006:5), menyatakan bahwa Dengan kemandirian, siswa cenderung belajar lebih baik, mampu memantau, mengevaluasi, dan mengatur belajarnya secara efektif, menghemat waktu secara efisien, akan mampu mengarahkan dan mengendalikan diri sendiri dalam berpikir dan bertindak, serta tidak merasa bergantung pada orang lain secara emosional.

Tingginya tingkat kemandirian belajar dapat diartikan bahwa siswa menerapkan

107 | Jurnal Pendidikan Akuntansi dan Keuangan 
pengaturan diri dengan baik karena tidak bergantung pada bantuan maupun arahan dari pihak lain dalam melakukan kegiatan belajar. Sebaliknya, kemandirian belajar yang rendah dapat berpengaruh pada rendahnya hasil belajar siswa. Karena, siswa dengan tingkat kemandirian belajar rendah dapat dikatakan memiliki pengaturan diri yang kurang baik, sehingga cenderung mengandalkan arahan maupun bantuan dalam melakukan kegiatan belajar, serta mengikuti jalannya kegiatan belajar tanpa menyadari kegiatan belajar seperti apa yang diperlukan sesuai dengan kebutuhan dirinya.

Fenomena rendahnya kemandirian belajar diketahui masih terdapat pada siswa kelas X dalam mata pelajaran Fisika di salah satu SMA Negeri Kota Bandung. Hasil Prapenelitian yang dilakukan oleh Saefullah dkk (2013) menunjukkan bahwa hanya sekitar $36,4 \%$ siswa yang merasa secara penuh memperhatikan proses pembelajaran; $15,1 \%$ yang secara penuh bertanggung jawab dalam mengerjakan pekerjaan rumah (PR); sekitar $6,1 \%$ siswa yang secara aktif mengikuti pembelajaran; dan sekitar $9,1 \%$ siswa berinisiatif mempelajari Fisika di rumah. Hal ini berdampak buruk bagi kemajuan siswa dalam proses pembelajaran, karena dalam penelitian tersebut dijelaskan bahwa hasil belajar siswa khususnya pada ranah kognitif dalam mata pelajaran Fisika yang mendapat peringkat terbawah jika dibandingkan dengan mata pelajaran lainnya. Selain itu, penelitian yang dilakukan oleh Nurrani (2009) yang dilakukan pada 144 orang siswa kelas XI SMKN 1 Katapang menyatakan bahwa Secara umum siswa SMK memiliki tingkat kemandirian

Tabel 1

Persentase Tingkat Kemandirian Belajar Siswa Kelas XI Akuntansi tahun ajaran 2016/2017 Dalam mata pelajaran Akuntansi Keuangan Di SMK Negeri 1 Bandung

\begin{tabular}{cccccc}
\hline \multirow{2}{*}{ No } & \multirow{2}{*}{ KLS } & JUMLAH & \multicolumn{3}{c}{ PERSENTASE } \\
\cline { 5 - 6 } & SISWA & TINGGI & SEDANG & RENDAH \\
\hline \multirow{2}{*}{1} & XI AK 1 & 35 Orang & $28,6 \%$ & $34,3 \%$ & $37,1 \%$ \\
2 & XI AK 2 & 35 Orang & $28,6 \%$ & $42,9 \%$ & $28,6 \%$ \\
3 & XI AK 3 & 35 Orang & $28,6 \%$ & $37,1 \%$ & $34,3 \%$ \\
\hline \multicolumn{1}{r}{} & RATA-RATA & & $\mathbf{2 8 , 6 \%}$ & $\mathbf{3 8 , 1 \%}$ & $\mathbf{3 3 , 3 \%}$ \\
\hline
\end{tabular}

Dari data di atas dapat dilihat masih terdapat siswa dengan persentase kemandirian belajar yang rendah. Hal ini menjadi fenomena yang perlu diteliti, karena kemandirian belajar merupakan sikap pribadi yang diperlukan oleh setiap siswa sebagai peserta didik sebagai belajar yang tersebar pada setiap kategori yaitu tinggi sekali sebesar 1,39\%; tinggi sebesar $38,2 \%$; sedang sebesar $41 \%$; rendah sebesar 17,4\%; dan rendah sekali sebesar 2,08\%. Dari data penelitian diketahui bahwa siswa SMK belum mencapai kemandirian belajar secara optimal yakni $60,5 \%$ sedangkan siswa yang telah mencapai kemandirian belajar secara optimal yakni sebesar 39,6\%. Hal ini menunjukkan bahwa tingkat kemandirian belajar siswa secara umum belum mencapai taraf yang optimal.

Wastono (2015) yang melakukan penelitian terhadap SMK Negeri di Kulon Progo menyatakan bahwa kemandirian belajar siswa kelas X Jurusan Teknik Pemesinan pada mata diklat Teknologi Mekanik masih rendah. Hal ini dibuktikan dengan hasil pra-penelitian yang menyatakan hanya sebesar $17 \%$ siswa bertanggung jawab atas permasalahan yang ada; sebesar 32\% mampu disiplin dalam proses belajar mengajar; dan sebesar $14 \%$ siswa yang mampu untuk aktif dan kreatif.

Rendahnya kemandirian belajar siswa khususnya dalam mata pelajaran Akuntansi Keuangan masih terdapat di SMK Negeri 1 Bandung (SMKN 1 Bandung) yang merupakan salah satu SMK dengan konsentrasi Bisnis dan Manajemen. Hal ini dapat dilihat dari data yang diperoleh dengan mengukur tingkat kemandirian belajar siswa menggunakan indikator yang dikembangkan oleh Zimmermann (1989:4) yaitu: (1) Timbulnya kesadaran akan pentingnya pengaturan diri; (2) Memantau efektivitas belajar; (3) Adanya harga diri; (4) Memiliki konsep diri; dan (5) Adanya aktualisasi diri. Data disajikan dalam tabel sebagai berikut: 
menghambat kemajuan siswa dalam sistem pembelajaran. Karena, hal tersebut dapat berdampak pada rendahnya hasil belajar siswa dan menjadi hambatan untuk melanjutkan proses pembelajaran selanjutnya. Rendahnya kemandirian belajar pada siswa juga dapat melemahkan kemampuan siswa dalam mengevaluasi hasil yang telah diperoleh sebagai acuan dalam menyusun strategi belajar guna meningkatkan hasil belajarnya. Selain itu, kemandirian belajar yang rendah dapat mempengaruhi siswa untuk terbiasa bergantung pada arahan maupun bantuan dari pihak lain dalam mengatur kegiatan belajar dan sumber belajar tertentu. Mengingat siswa saat ini telah didukung dengan berbagai kemajuan di bidang ilmu pengetahuan dan teknologi, seharusnya memudahkan siswa untuk memperoleh informasi dari berbagai sumber belajar dengan mengerahkan kemampuan dan keterampilannya.

\section{Landasan Teori}

Teori kognitif sosial yang dikembangkan oleh Bandura (1997:9) mengemukakan bahwa perilaku manusia sebagian besar ditentukan oleh sikap individu daripada lingkungan. Siswa sebagai individu yang hidup di lingkungan sosial dipengaruhi oleh karakteristik lingkungan yang membuatnya terdorong untuk berkembang. Adanya dorongan untuk berkembang dapat memberikan perubahan baik dalam sikap, cara berpikir, maupun cara pandangnya dalam menentukan langkah-langkah untuk mencapai tujuannya. Ormrod (2008:3) menyebutkan bahwa Teori kognitif sosial pendidikan merupakan perspektif teoritis yang berfokus pada bagaimana orang belajar dengan mengamati orang lain dan bagaimana dalam proses itu mereka mulai memegang kendali atas perilaku mereka sendiri.

Siswa yang memegang kendali atas kegiatan belajarnya dapat mengatur aktivitas belajar yang meliputi pemilihan kegiatan belajar maupun strategi belajarnya tanpa bergantung pada arahan orang lain. Hal ini sejalan dengan penerapan kemandirian belajar. Menurut Zimmerman (1989:4), kemandirian belajar dapat digambarkan melalui tingkatan atau derajat yang meliputi keaktifan berpartisipasi baik itu secara metakognisi, motivasional, maupun perilaku dalam proses belajar. Kemandirian belajar perlu untuk ditingkatkan mengingat siswa harus dapat mengatur diri agar dapat mencapai hasil belajar yang diharapkan, maka perlu diketahui hal-hal yang dapat mempengaruhi kemandirian belajar siswa. Menurut Ormrod (2008:39), Dalam membentuk kemandirian belajar, siswa tidak hanya dituntut untuk mengatur perilaku, melainkan dapat mengatur proses-proses mental mereka sendiri. Lebih lanjut Ormrod mengemukakan bahwa Pembelajar yang mengatur diri biasanya memiliki self-efficacy yang tinggi akan kemampuan mereka menyelesaikan suatu tugas belajar dengan sukses. Mereka menggunakan banyak strategi agar tetap terarah pada tugas, dan memiliki cara menyenangkan untuk mengingatkan diri mereka sendiri pentingnya mengerjakan tugas dengan baik, atau menjanjikan diri mereka sendiri hadiah tertentu begitu suatu tugas selesai dikerjakan.

Goodman dan Smart (1999:42), menyatakan bahwa kemandirian mencakup tiga aspek, yaitu (1) Independent (ketidaktergantungan) yang didefinisikan sebagai perilaku yang aktifitasnya diarahkan pada diri sendiri, tidak mengharapkan pengarahan orang lain, dan bahkan berusaha untuk menangani masalahnya sendiri tanpa bantuan orang lain; (2) Autonomi, yaitu menetapkan hak dan mengurus sendiri atau disebut juga kecenderungan berperilaku bebas dan original; dan (3) Self-reliance merupakan perilaku yang didasarkan pada kepercayaan diri.

Sikap yang didasarkan pada kepercayaan diri diantaranya adalah keyakinan seorang individu bahwa dirinya mampu untuk melakukan atau mengusahakan serangkaian upaya guna mencapai hasil yang ia harapkan. Hal ini sejalan dengan pengertian self-efficacy. Zimmerman (1989:5) menyebutkan bahwa terdapat beberapa faktor yang menghambat penerapan kemandirian belajar, yaitu (1) Siswa mungkin tidak percaya bahwa proses kemandirian belajar yang berhasil itu diperlukan, paling tidak pada konteks pembelajaran tertentu; (2) Siswa mungkin tidak percaya bahwa mereka dapat berhasil memperoleh respon yang efektif dari penerapan kemandirian belajar; (3) Siswa mungkin kurang berkeinginan untuk mencapai tujuan atau hasil pembelajaran tertentu yang

109 | Jurnal Pendidikan Akuntansi dan Keuangan 
dapat memotivasi mereka untuk menerapkan kemandirian belajar.

Dari faktor-faktor tersebut adanya rasa tidak percaya dalam diri siswa menjadi hambatan untuk menerapkan kemandirian belajar, sehingga siswa perlu dorongan keyakinan dalam dirinya bahwa siswa mampu menerapkan kemandirian belajar untuk mencapai tujuan yang diharapkan. Sejalan dengan teori kognitif sosial Bandura yang menjelaskan bahwa perilaku manusia sebagian besar ditentukan oleh individu sendiri daripada lingkungan, artinya siswa sebagai seorang individu yang merasakan hambatan dalam menerapkan kemandirian belajar dapat meningkatkan kemandirian belajarnya selama siswa memiliki keyakinan bahwa dirinya mampu menerapkan kemandirian belajar untuk mencapai tujuan yang diharapkan. Semakin tinggi tingkat keyakinan yang dimiliki siswa akan mempengaruhi tingginya kemandirian belajar yang diterapkan. Keyakinan diri yang dimaksud dalam teori kognitif sosial dalah selfefficacy.

Schunk (2012:553) mengemukakan bahwa Dalam menerapkan kemandirian belajar, siswa dihadapkan pada berbagai pilihan, tergantung pada proses seperti nilai, tujuan dan self-efficacy siswa. Seseorang dengan selfefficacy yang tinggi akan percaya dapat menghadapi segala situasi tertentu dan cenderung memandang masalah maupun situasi yang sulit sebagai sebuah tantangan karena selalu memiliki keyakinan untuk meraih kesuksesan.

Dalam hal belajar, tujuan yang hendak dicapai adalah pemahaman materi pelajaran serta hasil belajar yang optimal. Adanya selfefficacy yang tinggi pada diri siswa memungkinkan timbulnya kesadaran untuk belajar dan menerapkan kegiatan belajar mandiri, meliputi pengaturan waktu belajar, menentukan kegiatan dan strategi belajar yang cocok untuk memahami informasi belajar, dan mengevaluasi hasil belajar.

Penelitian yang telah dilakukan oleh Pintrich dan De Groot (1990), mendapati bahwa siswa yang memiliki kemandirian belajar menggunakan motivasi instrinsik dan self-efficacy yang tinggi. Individu yang memiliki kemandirian belajar yang tinggi cenderung belajar lebih baik karena mampu memantau, mengevaluasi, dan mengatur belajarnya secara efektif, menghemat waktu dalam menyelesaikan tugasnya, mengatur belajar dan waktu secara efisien. Hasil penelitian Wibasuri dan Lilyana (2014) menunjukkan bahwa mahasiswa dengan tingkat self-efficacy yang tinggi menunjukkan derajat kemandirian belajar yang tinggi juga. Berdasarkan penjelasan tersebut, dapat disimpulkan bahwa kemandirian belajar dapat dipengaruhi oleh self-efficacy.

Kemandirian belajar menjadi fenomena yang perlu diteliti karena siswa sebagai peserta didik memiliki tujuan yang ingin diraih. Dalam hal belajar, tujuan siswa adalah memiliki pemahaman yang tinggi tentang materi pelajaran serta hasil belajar yang optimal. Terdapat proses-proses yang dapat dijalankan untuk mendukung siswa dalam mencapai tujuan tersebut, yaitu melalui penerapan kemandirian belajar yang mengatur kegiatan belajar siswa tanpa bergantung pada arahan maupun bantuan pihak lain sehingga dapat dilakukan secara rutin sesuai kebutuhan siswa. Dengan menerapkan kemandirian belajar, siswa dapat meningkatkan kemampuan dirinya untuk mencapai tujuan belajar yang diharapkan secara optimal dan efektif karena tidak bergantung pada arahan maupun bantuan dari pihak lain. Dalam Akuntansi Keuangan, dibahas teori dan praktik yang menjadi dasar untuk mata pelajaran Akuntansi lainnya seperti Akuntansi Perusahaan Dagang dan Komputerisasi Akuntansi. Akuntansi Keuangan di SMK khususnya jurusan Akuntansi mulai dipelajari pada jenjang kelas XI, sehingga kemandirian belajar siswa dalam Akuntansi Keuangan di kelas XI dapat mempengaruhi kualitas belajar siswa di jenjang berikutnya.

\section{Metode Penelitian}

Tujuan dari penelitian ini adalah untuk mengetahui bagaimana gambaran self-efficacy dan kemandirian belajar siswa kelas XI Akuntansi tahun ajaran 2016/2017 dalam mata pelajaran Akuntansi Keuangan di SMK Negeri 1 Bandung, dan untuk mengetahui pengaruh variabel self-efficacy terhadap variabel kemandirian belajar. Untuk itu dalam penelitian ini digunakan metode deskriptif dan verifikatif.

\section{Populasi dan Sampel}

Populasi yang digunakan dalam penelitian ini adalah seluruh siswa kelas XI kompetensi keahlian Akuntansi tahun ajaran 2016/2017 di 
SMK Negeri 1 Bandung yang terdiri dari 105 siswa

Teknik sampling yang digunakan adalah sampling jenuh atau dengan istilah lain adalah sensus. Sampel yang digunakan adalah seluruh siswa kelas XI Akuntansi tahun ajaran 2016/2017 yang berjumlah 105 orang.

\section{Teknik Pengumpulan Data}

Dalam penelitian ini, peneliti menggunakan studi lapangan (field search) berupa kuisioner/angket. Dalam hal ini, peneliti memberikan sejumlah pernyataan dan alternatif jawaban berkaitan dengan self-efficacy dan kemandirian belajar yang secara bebas dapat dipilih oleh siswa sesuai dengan pendapat/pilihannya. Adapun bentuk angket untuk setiap variabel sesuai dengan karakteristiknya masing-masing, yang dijelaskan sebagai berikut:

\section{Self-efficacy}

Item pernyataan dalam angket selfefficacy dibuat berdasarkan indikator dalam penelitian yang dilakukan oleh Fitriani (2016), yang dikembangkan berdasarkan dimensi selfefficacy, yaitu level atau magnitude, strength, dan generality. Penyusunan item pernyataan disesuaikan berkaitan dengan kemandirian belajar dan tuntutan akademik siswa. Bandura (2006:312) mengemukakan bahwa: skala yang lebih baik digunakan untuk mengukur self-efficacy adalah 11 respon sikap dengan interval $0-10$ atau $0-100$ daripada menggunakan lima pernyataan sikap. Angka 0 berarti tidak mampu, 5 berarti cukup yakin mampu, 10 berarti sangat yakin mampu.

\section{Kemandirian Belajar}

Item pernyataan pada variabel kemandirian belajar disusun berdasarkan ciri ciri kemandirian belajar yang terdapat dalam Zimmerman (1989:4), yaitu: (1) Kesadaran akan pentingnya pengaturan diri; (2) Memantau efektivitas pembelajaran; (3) Harga diri; (4) Memiliki konsep diri; dan (5) Adanya aktualisasi diri. Skala yang digunakan untuk mengukur variabel kemandirian belajar adalah skala numerik (numerical scale) lima titik dengan kata sifat berkutub dua pada kedua ujungnya. Poin satu adalah terendah dan poin lima adalah tertinggi.

\section{Teknik Analisis Data dan Pengujian Hipotesis}

Teknik analisis data untuk memperoleh hasil sesuai dengan tujuan penelitian. Dalam penelitian ini digunakan uji instrumen penelitian, analisis deskriptif, serta pengujian hipotesis.

\section{Uji Instrumen Penelitian}

\section{Uji Validitas}

Dalam penelitian ini digunakan rumus Pearson Product Moment Correlation dengan rumus sebagai berikut:

$$
\begin{aligned}
& r=\frac{n\left(\sum X Y\right)-\left(\sum X\right)\left(\sum Y\right)}{\sqrt{\left\{n\left(\sum X^{2}\right)-\left(\sum X\right)^{2}\right\}\left\{n\left(Y^{2}\right)\left(\sum Y\right)^{2}\right\}}} \\
& \text { (Arikunto, 2010:213) } \\
& \text { Keterangan: } \\
& \mathrm{r} \quad=\text { Koefisien validitas item yang }
\end{aligned}
$$

Bila $\mathrm{r}_{\text {hitung }}>\mathrm{r}_{\text {tabel }}(\alpha=0,05)$ berarti item tersebut valid dan layak untuk digunakan dalam angket penelitian. Sebaliknya, jika $\mathrm{r}_{\text {hitung }} \leq \mathrm{r}_{\text {tabel }}$ item tersebut dinyatakan tidak valid

\section{Uji Reliabilitas}

Rumus yang digunakan dalam penelitian ini adalah rumus Alpha Cronbach sebagai berikut:

$$
r=\left(\frac{k}{k-1}\right) \begin{gathered}
\left(1-\frac{\Sigma \sigma b^{2}}{\sigma t^{2}}\right) \\
2010: 239)
\end{gathered} \quad \text { (Arikunto, }
$$

\section{Keterangan :}

$\mathrm{r}=$ Koefisien reliabilitas

instrumen

$\mathrm{k}=$ Banyaknya bukti penyertaan atau banyak soal

$$
\begin{array}{ll}
\Sigma \sigma b^{2} & =\text { Total varians butir } \\
\sigma \mathrm{t}^{2} & =\text { Total varians } \\
\text { Rumus } & \text { untuk mencari variansnya }
\end{array}
$$

adalah : 


$$
\sigma b^{2}=\frac{\sum x^{2}-\left[\frac{\sum(x)^{2}}{N}\right]}{N}
$$

(Arikunto, 2010:239)

Keterangan :

$\Sigma \sigma \mathrm{b}^{2}=$ Varians butir

$\Sigma \mathrm{x} \quad=$ Jumlah skor

$\mathrm{N} \quad=$ Jumlah responden uji coba

Bila $r_{\text {hitung }}>r_{\text {tabel }}$ berarti item tersebut reliabel serta layak untuk digunakan dalam angket penelitian. sebaliknya, jika instrumen dinyatakan tidak reliabel, maka item tersebut tidak dapat dipercaya. Pengujian reliabilitas instrumen dalam penelitian ini dilakukan terhadap 20 orang responden dengan tingkat signifikansi $(\alpha)$ sebesar 0,05 .

\section{Pengujian Hipotesis \\ Hipotesis Penelitian}

Hipotesis penelitian yang dijabarkan dalam penelitian ini adalah Self-efficacy berpengaruh positif terhadap kemandirian belajar. Hipotesis Statistik. Untuk mengetahui diterima atau tidaknya hipotesis penelitian digunakan pengujian dengan menggunakan rumus statistik, sehingga hipotesis penelitian perlu diubah menjadi hipotesis statistik. Riduwan (2008:42) mengemukakan bahwa hipotesis statistik adalah pernyataan statistik tentang populasi yang diteliti. Dalam hipotesis statistik, digunakan hipotesis nol dengan lambang $\mathrm{H}_{0}$ dan hipotesis alternatif dengan lambang $\mathrm{H}_{1}$. Hipotesis statistik parametrik dalam penelitian ini dinyatakan sebagai berikut:

$\mathrm{H}_{0}: \rho=0 \quad$ Self-efficacy tidak berpengaruh terhadap kemandirian belajar siswa

$\mathrm{H}_{1}: \rho>0 \quad$ Self-efficacy berpengaruh positif terhadap kemandirian belajar siswa

Namun jika pengujian hipotesis menggunakan statistik non-parametrik, hipotesis statistik nonparametrik dalam penelitian ini dinyatakan sebagai berikut:

$\mathrm{H}_{0}: \mathrm{r}_{\mathrm{s}}=0 \quad$ Self-efficacy tidak berpengaruh terhadap kemandirian belajar siswa

$\mathrm{H}_{1}: \mathrm{r}_{\mathrm{s}}>0 \quad$ Self-efficacy berpengaruh positif terhadap kemandirian belajar siswa

Analisis data menggunakan korelasi Pearson Product Moment (PPM) yang bertujuan untuk mengetahui hubungan dan kontribusi variabel self-efficacy (X) dan variabel kemandirian belajar (Y). Rumus yang digunakan adalah sebagai berikut:

$$
r=\frac{n\left(\sum X Y\right)-\left(\sum X\right)\left(\sum Y\right)}{\sqrt{\left\{n\left(\sum X^{2}\right)-\left(\sum X\right)^{2}\right\}\left\{n\left(Y^{2}\right)\left(\sum Y\right)^{2}\right\}}}
$$

(Riduwan, 2008:136)

Keterangan:

$\mathrm{R}=$ Koefisien korelasi

$\mathrm{X}=$ Skor total variabel $\mathrm{X}$

$\mathrm{Y}=$ Skor total variabel $\mathrm{Y}$

$\mathrm{N}=$ Banyaknya anggota sampel

Selanjutnya, untuk mengetahui

besarnya variabel self-efficacy (X) mempengaruhi variabel kemandirian belajar (Y) perlu diketahui koefisien determinan yang dapat dicari dengan rumus:

$$
\mathrm{KP}=\mathrm{r}^{2} \times 100 \% \quad \text { (Riduwan, }
$$$$
\text { 2008:136) }
$$

Hasil presentase koefisien determinasi diartikan sebagai besarnya pengaruh yang diberikan oleh variabel self-efficacy (X) terhadap variabel kemandirian belajar (Y), dan selanjutnya dijadikan acuan untuk menarik kesimpulan penelitian.

Dengan menggunakan statistik parametrik, untuk menguji keberartian koefisien korelasi digunakan rumus $t_{\text {hitung }}$ sebagai berikut:

$$
t_{\text {hitung }}=\frac{r \sqrt{n-2}}{\sqrt{1-r^{2}}}
$$

(Riduwan, 2008:137)

Keterangan :

$$
\begin{aligned}
& \mathrm{t}=\text { Uji signifikansi korelasi; } \\
& \mathrm{r}=\text { Koefisien korelasi PPM; } \\
& \mathrm{n}=\text { Jumlah sampel (responden) }
\end{aligned}
$$

Uji keberartian koefisien korelasi menggunakan rumus $t_{\text {hitung }}$ sebagai berikut:

$$
t_{\text {hitung }}=r_{s} \frac{\sqrt{n-2}}{\sqrt{1-r_{s}^{2}}}
$$

(Lind dkk, 2008:329)

$\mathrm{t}=$ Uji signifikansi korelasi;

$\mathrm{r}_{\mathrm{s}}=$ Koefisien korelasi Rank Spearman;

$\mathrm{n}=$ Jumlah sampel (responden)

Setelah dilakukan pengujian dengan menggunakan rumus statistik, selanjutnya diambil kesimpulan dengan langkah-langkah sebagai berikut (1) Menentukan tabel dalam tabel distribusi $t$ dengan tingkat derajat kebebasan (df) $=\mathrm{n}-2$ dan tingkat $\begin{array}{llll}\text { signifikansi } \quad(\alpha) \text { sebesar } & 0,05 \quad \text { (2) }\end{array}$ Membandingkan $t_{\text {hitung }}$ dengan $t_{\text {tabel }}$ untuk menerima atau menolak atau menerima hipotesis, dengan kriteria sebagai berikut :

Jika, 1. $\mathrm{t}_{\text {hitung }}>\mathrm{t}_{\text {tabel }}$, maka $\mathrm{H}_{0}$ ditolak dan $\mathrm{H}_{1}$ diterima; 2 . $\mathrm{t}_{\text {hitung }} \leq \mathrm{t}_{\text {tabel }}$, maka $\mathrm{H}_{0}$ diterima dan $\mathrm{H}_{1}$ ditolak. (3) Menarik kesimpulan (1) $\mathrm{H}_{0}$ 
diterima, berarti self-efficacy tidak berpengaruh terhadap Kemandirian belajar (2) $\mathrm{H}_{1}$ diterima, berarti self-efficacy berpengaruh positif terhadap Kemandirian belajar.

\section{Hasil dan Pembahasan}

Pembahasan ini disusun berdasarkan hasil penyebaran angket dan interpretasi pengolahan data yang diperoleh dari lapangan untuk mengetahui hasil penelitian sesuai dengan teori yang digunakan serta tujuan yang telah dijabarkan. Variabel self-efficacy diukur menggunakan 7 indikator yang terbagi menjadi 28 item pernyataan dengan 11 alternatif jawaban, sedangkan variabel kemandirian belajar diukur menggunakan lima indikator yang terbagi menjadi 19 item pernyataan dengan 5 alternatif jawaban. Penyebaran angket dilakukan kepada seluruh populasi siswa kelas XI Akuntansi tahun ajaran 2016/2017 di SMK Negeri 1 Bandung yang berjumlah 105 orang. Arah dan besar pengaruh self-efficacy terhadap kemandirian belajar dibuktikan dengan koefisien korelasi (r) dan koefisien determinan yang (KP) yang digambarkan sebagai berikut:

$\varepsilon=67,74 \%, \mathrm{KP}=32,26 \%$ dan $\mathrm{r}=0,568$

Hasil penelitian menunjukkan bahwa self-efficacy memiliki pengaruh sebesar $32,26 \%$ terhadap peningkatan variabel kemandirian belajar. Artinya, adanya peningkatan self-efficacy siswa dalam mempelajari mata pelajaran Akuntansi Keuangan akan berpengaruh pada peningkatan kemandirian belajarnya. Selebihnya, sebesar $67,74 \%$ dipengaruhi oleh faktor lain. Faktorfaktor yang dapat mempengaruhi kemandirian belajar selain self-efficacy yang disebutkan dalam penelitian ini adalah faktor perilaku (self-observation, self-judgement, dan selfreaction) dan faktor lingkungan (modeling)

Hasil penelitian di atas membuktikan pendapat Zimmermann (1989) yang menyebutkan bahwa dalam menerapkan kemandirian belajar, siswa dipengaruhi oleh rasa tidak percaya diri bahwa dirinya mampu menerapkan kemandirian belajar, sehingga siswa perlu dorongan keyakinan bahwa dirinya mampu menerapkan kemandirian belajar untuk dapat mencapai tujuan yang telah ditetapkan. Keyakinan tersebut adalah self-efficacy. Kemandirian belajar siswa kelas XI Akuntansi tahun ajaran 2016/2017 dalam mata pelajaran
Akuntansi Keuangan secara umum berada pada kategori sedang. Hal ini berarti siswa sudah cukup baik melaksanakan aktivitas belajar dalam mempelajari Akuntansi Keuangan dengan menerapkan pengaturan sendiri tanpa bergantung pada arahan dari pihak lain, namun masih perlu ditingkatkan karena tingkat kemandirian belajar dapat mempengaruhi siswa untuk mencapai tujuan belajar secara efektif dan optimal, dalam penelitian ini khususnya pada mata pelajaran Akuntansi Keuangan. Siswa dengan tingkat kemandirian belajar yang tinggi berarti secara optimal telah melaksanakan aktivitas belajar Akuntansi Keuangan dengan menerapkan pengaturan sendiri tanpa bergantung pada arahan dari pihak lain. Hal ini dapat mendorong siswa dalam mencapai tujuan belajar Akuntansi Keuangan yang diharapkan. Sebaliknya, siswa dengan tingkat kemandirian belajar yang rendah berarti menerapkan pengaturan diri yang kurang baik dalam belajar dan cenderung bergantung pada arahan pihak lain sehingga menghambat siswa dalam mencapai tujuan belajar. Berdasarkan hasil penyebaran angket, diketahui persentase tertinggi terdapat pada indikator memantau efektivitas pembelajaran yaitu sebesar 70,48\% atau sebanyak 74 siswa berada pada kategori tinggi. Hal ini berarti lebih dari setengah jumlah populasi siswa sangat mampu memantau keselarasan antara kegiatan belajar yang diterapkan dengan pencapaian tujuan yang ditetapkan. Dengan memantau efektivitas pembelajaran, siswa dapat mengevaluasi kegiatan belajar yang telah dilakukan untuk menentukan cara, strategi, maupun sumber-sumber belajar baru jika diperlukan. Persentase terendah terdapat pada indikator harga diri, yaitu sebesar $20 \%$ atau sebanyak 21 orang siswa berada pada kategori tinggi. Hal ini berarti sebesar $80 \%$ atau sebanyak 84 orang siswa belum secara optimal memahami adanya sesuatu yang berharga dalam dirinya yang menjadi kelebihan dibandingkan dengan orang lain. Adanya harga diri yang dirasakan siswa memberikan kekuatan dorongan untuk mencapai tujuan karena siswa merasa bahwa dirinya memiliki kelebihan yang tidak dimiliki orang lain. Teori kognitif sosial yang menjadi dasar dari teori kemandirian belajar menyebutkan bahwa perilaku individu sebagian besar dipengaruhi oleh individu itu sendiri dibandingkan lingkungan. Artinya, adanya keyakinan dalam

113 | Jurnal Pendidikan Akuntansi dan Keuangan 
diri siswa dapat mendorong tercapainya tujuan mempelajari Akuntansi Keuangan yang telah ditetapkan. Keyakinan siswa bahwa dirinya mampu melakukan serangkaian kegiatan belajar meliputi pengaturan waktu belajar, penentuan strategi, cara, maupun sumber belajar yang sesuai dengan kebutuhannya dapat mendorong siswa untuk mencapai tujuan belajar yang ditetapkan. Ketika siswa melakukan serangkaian kegiatan belajar tersebut, siswa sedang menerapkan kemandirian belajar. Secara umum, tingkat self-efficacy siswa kelas XI Akuntansi tahun ajaran 2016/2017 dalam mata pelajaran Akuntansi Keuangan di SMK Negeri 1 Bandung berada pada kategori sedang. Hal ini berarti siswa cukup optimal dalam keyakinannya untuk melakukan serangkaian kegiatan dalam upaya mencapai tujuan yang diharapkan. Secara teori dapat diketahui bahwa self-efficacy dapat mempengaruhi kemampuan siswa dalam menerapkan kemandirian belajar sebagai upaya yang dapat dilakukan untuk mencapai tujuan belajarnya, hal ini sejalan dengan Schunk (2012) yang menyatakan bahwa orang-orang dengan self-efficacy yang tinggi cenderung mengeluarkan usaha yang lebih banyak dan bertahan pada suatu tugas karena mereka memiliki keyakinan bahwa mereka akan berhasil dalam mencapai tujuan, begitupun sebaliknya. Siswa dengan selfefficacy yang tinggi selalu merasa optimis dalam mencapai tujuan belajar yang telah ditetapkan, untuk itu siswa menerapkan kemandirian belajar sebagai upaya yang mendorongnya untuk mencapai tujuan belajar. Keyakinan dalam diri siswa bahwa dirinya mampu menerapkan kemandirian belajar khususnya dalam mempelajari mata pelajaran Akuntansi Keuangan dapat mendorong siswa dalam memahami materi maupun mencapai hasil belajar yang optimal dalam mata pelajaran Akuntansi Keuangan. Sebaliknya, siswa dengan tingkat self-efficacy yang rendah berarti kurang yakin akan kemampuan dirinya sehingga siswa cenderung mudah menyerah dan kurang memaksimalkan kemampuannya dalam melakukan serangkaian upaya untuk mencapai tujuan yang telah ditetapkan. Berdasarkan hasil penyebaran angket, diketahui persentase tertinggi terdapat pada indikator berpedoman pada pengalaman hidup sebagai suatu langkah untuk mencapai keberhasilan, yaitu sebesar $41,91 \%$ atau sebanyak 44 orang siswa berada pada kategori tinggi. Hal ini berarti hampir setengah dari jumlah populasi siswa sangat yakin dapat berhasil dalam mencapai tujuan yang telah ditetapkan dengan menjadikan pengalaman sebelumnya sebagai acuan. Jika pengalaman sebelumnya berupa kegagalan, siswa akan menjadikan pengalaman sebelumnya sebagai acuan untuk menentukan strategi baru agar tidak mengalami kegagalan yang sama, namun jika pengalaman sebelumnya berupa keberhasilan siswa akan terdorong untuk menentukan tujuan baru yang melampaui hasil sebelumnya karena memiliki keyakinan kuat untuk dapat berhasil. Persentase terendah terdapat pada indikator menyikapi situasi dan kondisi yang beragam dengan cara yang baik dan positif, yaitu hanya sebesar $5,71 \%$ atau sebanyak 6 orang siswa berada pada kategori tinggi, hal ini berarti sebesar 94,29\% atau sebanyak 99 orang siswa berada pada kategori sedang dan rendah. Artinya, hampir seluruh populasi siswa belum secara optimal meyakini bahwa dirinya mampu melakukan upaya dengan baik dan tetap berpikiran positif dalam mengatasi situasi yang dihadapi. Santrock (2003) menyatakan bahwa terdapat empat cara yang dapat dilakukan untuk meningkatkan self-efficacy siswa, yaitu menentukan suatu tujuan yang realistis untuk dicapai, menjadikan kegagalan sebagai pelajaran untuk mencapai tujuan yang telah ditetapkan, tetap bertahan dan fokus terhadap upaya yang telah direncanakan, serta membuat daftar urutan situasi yang dapat diatasi.

Hasil analisis korelasi membuktikan bahwa terdapat korelasi positif antara selfefficacy dan kemandirian belajar. Hasil analisis korelasi kemudian digunakan untuk mengetahui besarnya pengaruh self-efficacy terhadap kemandirian belajar serta melakukan uji hipotesis (uji t) untuk mengetahui kesimpulan dari hasil penelitian. Setelah melakukan uji t, diketahui thitung sebesar 7,004 dan $t_{\text {tabel }}$ sebesar 1,65978. Karena $t_{\text {hitung }}>t_{\text {tabel }}$, maka hipotesis diterima. Artinya, ditarik kesimpulan bahwa self-efficacy berpengaruh positif terhadap kemandirian belajar siswa kelas XI Akuntansi tahun ajaran 2016/2017 dalam mata pelajaran Akuntansi Keuangan di SMK Negeri 1 Bandung. Self-efficacy secara positif dapat mempengaruhi kemandirian belajar karena self-efficacy menimbulkan adanya dorongan keyakinan bahwa siswa mampu menerapkan serangkaian kegiatan 
dalam upaya mencapai tujuan belajar. Siswa yang merasa yakin dapat menerapkan kegiatan belajar akan menentukan waktu, cara, maupun media belajar yang sesuai dengan kebutuhannya tanpa bergantung pada arahan maupun bantuan dari pihak lain. Tinggi atau rendahnya keyakinan diri dapat mempengaruhi siswa untuk bertahan dalam serangkaian kegiatan yang telah disusun untuk mencapai tujuan belajar, sehingga tingginya tingkat selfefficacy siswa dapat meningkatkan kemandirian belajar siswa, begitupun sebaliknya. Diterimanya hipotesis penelitian ini menunjukkan bahwa untuk meningkatkan kemandirian belajar siswa kelas XI Akuntansi tahun ajaran 2016/2017 SMK Negeri 1 Bandung dalam mata pelajaran Akuntansi Keuangan dapat melalui peningkatan selfefficacy. Hal ini memperkuat penelitian yang dilakukan Wibasuri dan Lilyana (2014) yang menunjukkan bahwa mahasiswa dengan tingkat self-efficacy yang tinggi juga menunjukkan derajat kemandirian belajar yang tinggi.

\section{Kesimpulan dan Saran}

Berdasarkan pembahasan penelitian yang telah dijelaskan dapat disimpulkan yaitu Setengah dari jumlah populasi siswa kelas XI Akuntansi tahun ajaran 2016/2017 di SMKN 1 Bandung memiliki tingkat selfefficacy yang tergolong cukup baik dalam mata pelajaran Akuntansi Keuangan. Hal ini dibuktikan dengan persentase tingkat self-efficacy siswa kelas XI Akuntansi dalam mata pelajaran Akuntansi Keuangan secara umum sebesar 50,48\% berada pada kategori sedang, artinya mayoritas siswa secara umum cukup optimal dalam keyakinannya untuk melakukan serangkaian kegiatan dalam upaya mencapai tujuan yang diharapkan.

Hampir setengah dari jumlah populasi siswa kelas XI Akuntansi tahun ajaran 2016/2017 di SMKN 1 Bandung memiliki tingkat kemandirian belajar yang cukup baik dalam mata pelajaran Akuntansi Keuangan. Hal ini dibuktikan dengan persentase tingkat kemandirian belajar siswa kelas XI Akuntansi dalam mata pelajaran Akuntansi Keuangan secara umum sebesar $47,62 \%$ berada pada kategori sedang dan tinggi, artinya mayoritas siswa secara umum sudah cukup baik dalam melaksanakan aktivitas belajar dengan menerapkan pengaturan sendiri tanpa bergantung pada arahan dari pihak lain.

Self-efficacy berpengaruh positif terhadap kemandirian belajar siswa kelas XI Akuntansi tahun ajaran 2016/2017 dalam mata pelajaran Akuntansi Keuangan di SMKN 1 Bandung.

Saran

Hasil penelitian yang diperoleh dapat diketahui bahwa self-efficacy memiliki pengaruh positif untuk meningkatkan kemandirian belajar siswa. Sehingga dalam meningkatkan kemandirian belajar siswa perlu meningkatkan self-efficacy dalam dirinya. Peneliti mengemukakan beberapa saran untuk meningkatkan self-efficacy siswa terkait dengan pembahasan penelitian, yaitu (1) Siswa secara rutin berlatih mengerjakan soal Akuntansi Keuangan agar terbiasa mengerjakan soal-soal yang mudah maupun sulit; (2) Siswa bergaul dengan orang-orang yang bersemangat dalam belajar Akuntansi Keuangan (3) Siswa membuat target belajar Akuntansi Keuangan yang harus dicapai sebagai acuan untuk berkembang (4) Siswa bersikap tenang dalam belajar; (5) Siswa menjadikan hasil yang telah diperoleh sebagai sarana untuk belajar.

\section{Daftar Pustaka}

Arikunto, S. (2010).Prosedur Penelitian.Jakarta: PT. Rineka Cipta.

Bandura, A, (1997). Self Efficacy : The Exercise Of Control.New York: Freeman and Company. (1997). Self Efficacy in Changing

Socities.Cambridge: University Press

Brookfield, Stephen.( 2012). Understanding and Facilitating Adult Learning. Josey Bass Publisher : San Fransisco

Goodman and Smart.(1999).Emotional Intelligence.New York: Bantam Books.

Ihsan, F.(2010).Dasar-dasar Kependidikan.Jakarta: PT. Rineka Cipta.

Lind, Douglas A dkk.(2008).Teknik-teknik Statistika dalam Bisnis dan Ekonomi Menggunakan Kelompok Data Global.Jakarta: Salemba Empat

115 | Jurnal Pendidikan Akuntansi dan Keuangan 
Nilson, Linda.(2013).Creating Self-Regulated Learners: Strategies to Strengthen Students' SelfAwareness and Learning Skills:Stylus Publishing

Ormrod, Jeanne Ellis.(2008).PSIKOLOGI PENDIDIKAN: Membantu Siswa Tumbuh dan Berkembang. Jakarta: Penerbit Erlangga

Program Studi Pendidikan Akuntansi.(2014).Pedoman Operasional Penulisan Skripsi.Bandung: Program Studi

Pendidikan Akuntansi Universitas Pendidikan Indonesia

Riduwan.(2011).Metode dan Teknik Menyusun Tesis.Bandung: Alfabeta

Santrock, J. W. (2003).Perkembangan

Remaja.Jakarta: Airlangga

Schunk, Dale H. (2012).Learning Theories.Jakarta: Pustaka Pelajar

Slavin, Robert E.(2009). PSIKOLOGI

PENDIDIKAN:Teori dan Praktik Jilid 2. Jakarta: Indeks.

Sudjana, (2004).STATISTIKA: Untuk Ekonomi dan Niaga.Bandung: Penerbit Tarsito

Sugiyono.(2012).Metode Penelitian Kuantitatif Kualitatif dan $R \& D$.Bandung: $\quad$ Alfabeta (2013).Statistika

untuk

Penenlitian.Bandung: Alfabeta.

Sukarno, Anton.(2011). Ciri-Ciri Kemandirian

Belajar. Jakarta: Kencana Prenada Media.

Uno, Hamzah B.(2015).Teori Motivasi dan Pengukurannya Analisis di Bidang Pendidikan. Jakarta: Bumi Aksara.

Zimmerman,BJ.(1989).Self-regulated Learning and Academic Achievement: Theory, Research, and Practice.New York: Springer-Verlag New York Inc.

Bandura, A.(2006)."Guide for Constructing Selfefficacy Scales"

Achmad, Ida Farida.(2008).Pengaruh Kemandirian Belajar dan Disiplin Belajar terhadap Prestasi Belajar Siklus Akuntansi Siswa Kelas X SMK Negeri 7 Yogyakarta Tahun Ajaran 2007/2008. Skripsi. FE UNY.

Hidayati, Kana dan Endang

Lisyani.(2010).Improving Instruments of Student's Regulated
Learning.Jurnal.Program Studi Pendidikan Matematika.FMIPA UNY

Nurrani,Siti.(2009).Profil Kemandirian Belajar Siswa SMK: Studi Kearah Pengembangan Program Bimbingan Belajar Siswa SMKN 1 Katapang Kab. Bandung Tahun Ajaran 2008-2009.Skripsi.FIP UPI

Pintrich, P.R., E.V De Groot.(1990). Motivational and self-regulated component of classroom Journal of Educational Psychology, 82, 1, 33-40.

Saefullah, A.,dkk.(2013).Hubungan Antara Sikap Kemandirian Belajar dan Prestasi Belajar Siswa Kelas X Pada Pembelajaran Fisika Berbasis Portofolio.Jurnal.Program Studi

Pendidikan Fisika.FMIPA UPI

Schunk, D.H.(1990)."Goal Setting and Self-efficacy During Self-regulated Learning"

Sumarmo,U.(2006)."Kemandirian Belajar: Apa, Mengapa, dan Bagaimana dikembangkan pada Peserta Didik".

Susilawati,Desi.(2009). Upaya Meningkatkan Kemandirian Belajar Dan

Kemampuan Matematika Siswa Kelas X SMA N 1 Gamping Dengan

Menggunakan Lembar Kerja Siswa.

Program Studi Pendidikan

Matematika.FPMIPA UPI

Wastono, FX.(2015).Peningkatan Kemandirian Belajar Siswa SMK pada Mata Diklat Teknologi Mekanik dengan Metode Problem Based Learning.Jurnal.SMKN 2 Pengasih Kulon Progo

Wibasuri, Anggalia dan Besti Lilyana.(2014)"Determinasi Self-efficacy dalam Kemandirian Belajar Mahasiswa pada Perguruan Tinggi Swasta di Bandar

Lampung".

Fitriani, Suci Nurul.(2016).Hubungan Self-efficacy dan Dukungan Sosial .Skripsi.FIP UPI

Zimmerman, B.J and Martinez-Pons.(1990).” Student Differences in Self-regulated Learning: $\quad$ Relating Grade, Sex, and Giftedness to Self-efficacy and Strategy Use" 